\title{
Language-Learner Strategy Instruction and English Achievement: Voices from Ghana
}

\author{
John T. Agor ${ }^{1}$ \\ ${ }^{1}$ Department of Linguistics, University of Ghana, Legon, Ghana \\ Correspondence: John T. Agor, Department of Linguistics, University of Ghana, P. O. Box LG61, Legon, Ghana.
}

Tel: 223-208-198-158. E-mail: jtagor@ug.edu.gh

\author{
Received: March 3, 2014 Accepted: April 6, 2014 Online Published: May 15, 2014 \\ doi:10.5539/elt.v7n6p175 URL: http://dx.doi.org/10.5539/elt.v7n6p175
}

The research is self-financed.

\begin{abstract}
This paper presents the results of a one-year longitudinal study which sought to investigate the effect that strategy instruction may have on English language achievement. Two classes of junior high school students at Madina in Ghana were involved in an experiment. The experimental class was taught various language-learner strategies both implicitly and explicitly as part of their English lessons. The control class was taught the same contents excluding language-learner strategies. Pre-test and post-test proceedings were video-taped and analysed. During post-test activities, the experimental class displayed 17 different language-learner strategies with facility while the control class deployed 7. At the end of the academic year, the English language results of the two groups were compared: $96.5 \%$ of the experimental class obtained Grade "One" while $24 \%$ of the control group obtained that Grade. The results suggest that one sure way to attain the desired levels of achievement in English at the basic school level in Ghana is to popularise language-learner strategy instruction.
\end{abstract}

Keywords: language-learner strategies, longitudinal study, strategy instruction, junior high school

\section{Introduction}

Ghana, a post-colonial country, with a multilingual population of 25.37 million people (World Bank Population Data, 2012), has about forty-five (Dakubu (ed.) 1988, p.10) different indigenous languages. English, her official language, is the language for educational placement and career advancement. In spite of this importance of English in the country, Chief Examiners' reports received in recent years from the West African Examinations Council (WAEC), the examining body for public examinations in the West African sub-region, have regularly indicated that most students who fail lacked the requisite proficiency in English and this is evident in their inability to express themselves clearly in the language. The aim of this study, therefore, is to investigate, in the Ghanaian context, the benefits of language-learner strategy instruction at the basic school level. The purpose is to identify the positive features of strategy instruction with the view of adapting them as a way of stepping up attainment in English in Ghanaian schools.

Findings from recent studies (including Schwartz, Mendoza, \& Meyer, 2013; Wong \& Nunan, 2011; Vandergrift, 2003) suggest that when language learners are coached in language-learner strategies they stand a better chance of becoming proficient in the target language. For example, Wong and Nunan $(2011$, p. 146) are confident that strategy training can lead to more effective learning. Unfortunately, the situation in Ghana has been that, ever since attempts were made to train indigenous teachers for the local schools in 1842, in terms of strategy use, the focus has always been on the teacher. But Oxford (1993, p. 11) acknowledges that "learning begins with the learner"; and Griffiths (2003, p. 14) confirms this fact by saying that "even with the best teachers and methods, students are the only ones who can actually do the learning". The current researcher shares the view that if learners are exposed to learner strategies, they will take charge of their own learning and will eventually excel.

\subsection{Hypothesis}

From the aforementioned, the following hypothesis will be tested: If all other variables remain constant, basic school students in Ghana who have received instruction in language-learner strategies will perform better in 
English than those who have not been exposed to language-learner strategies. The research design adopted will allow the performances of the two groups to be compared. The prediction is that learners who will be coached in language-learner strategies will outperform their counterparts who will not be coached. The rationale is that if this hypothesis is confirmed in the Ghanaian context, practitioners in Ghana are likely to implement strategy training in their schools for improved outcomes.

\subsection{Theoretical Framework}

Based on the aim and the purpose, the current study adapts the action research procedure. Action research is a kind of study that is carried out by a practitioner, usually in collaboration with others, and is concerned with identification and solution of problems in a specific educational setting. It is aimed at improving the current state of affairs within the educational context. The goals of action research include gaining insight into the teaching/learning process, developing reflective practice in teaching, effecting positive change in the school environment and on educational practices in general, and improving student outcomes (Mills 2011, p. 5).

Because action research is an emerging framework in educational research, several but similar models have been put forth. For example, Coghlan and Brannick (2009, p. 4) suggest that the four stages contained in action research are constructing, planning, taking action, and evaluating action. Burns $(2010$, p. 8$)$ talks about planning, action, observation, and reflection as the four main processes involved in action research. She asserts that the central idea of the action part of action research is to "intervene in a deliberate way in the problematic situation in order to bring about changes and improvement in practice" (Burns, 2010, p. 2). In relation to language teaching, Nunan (1992, p. 18) had earlier explained that the action research procedure involves five stages. First, the research is initiated by a practitioner/researcher and is derived from a real problem in an educational set-up that needs to be confronted. Second, the initiator collaborates with a practitioner or a university-based researcher as the case may be. Third, objective data in the form of learner language and classroom interaction are collected for analysis and interpretation. Next, the results are disseminated through seminars and conference paper presentations to colleagues and also through publications. Finally, the project takes the form of an on-going cycle in which the instructor "reflects on, returns to, and extends the initial enquiry" (Nunan, 1992, p. 18).

Three defining characteristics of action research can be deduced from the aforementioned. First, it is carried out by a practitioner, in this case someone who works in an educational institution (e.g. a school teacher, school administrator, university-based researcher); second, it is collaborative; and third, it is aimed at changing things. Currently, action research has become increasingly significant in language education. Practitioners engage in action research for various reasons. Action research has the potential of leading to new insights into language teaching and learning. Also, some of the knowledge validated in certain theories may be confirmed or disconfirmed through the use of action research. Additionally, research questions asked in action research relate to classroom decision making. Finally, the results of action research have durable impact on the practice of teaching.

The action research procedure was adopted in the current study because the study is meant to solve a real problem at the basic school level in Ghana. In other words, it is aimed at improving the current state of affairs within the educational context in relation to student attainment in English. The current situation in Ghana is that, each year, a large number (about 50\%) of Basic School leavers do not get placement into senior high school because they do not obtain the requisite grade in English. It is therefore envisaged that implementing action research as framework will make practitioners associate themselves with the study. In other words, the results may have the potential to inspire English teachers and school heads to expose their students to the use of productive language-learner strategies for improved student outcome.

\section{Literature Review}

Although there is lack of consensus in the literature concerning the effect of strategy instruction (e.g. Kellerman, 1991; Rees-Miller, 1993; and Gillette, 1994 have raised questions about various aspects of strategy instruction), findings from recent studies (e.g. Macaro, 2001; Carrier, 2003; Choudhary, Al-thubaiti, \& Uthman, 2013; Sadeghi \& Khonbi, 2013) support strategy instruction. A popular view currently held is that language-learner strategies are teachable and that learners can benefit enormously from training in learner strategies (Oxford \& Nyikos, 1989, p. 291). Below are some reports of studies on the effects of learner-strategy training.

Faucette (2001) presents a pedagogical perspective of the benefits of teaching communication strategies to second/foreign language learners and the need to produce adequate teaching materials for the purpose. She gives an exposition of some conceptualisations of communication strategies and discusses the controversies concerning teaching communication strategies, arguing in favour of it. She explains that effective strategies used to overcome communication difficulties are of crucial importance for second-language learners. Therefore, 
second-language learners might benefit from instruction on how to overcome such difficulties. She is of the opinion that an underlying assumption of research on learner autonomy is that, in order to equip the learner with the tools to eventually become autonomous, "training must necessarily take place". She explains that, in self-directed learning, the teacher acts more as a facilitator who provides the students with the tools to become autonomous through opportunities to learn and through strategy instruction (Faucette, 2001, p. 9). She asserts:

I have proposed a number of arguments in favour of teaching communication strategies. These are based on evidence from the research on: language learning strategies, listening strategies, strategy transfer, second language learning, procedural vocabulary, cultural differences in language use, learning autonomy, and teaching and the teachability of communication strategies (Faucette, 2001, p. 11).

Faucette (2001) concludes that since non-native speakers often find themselves lacking the very resources needed to communicate their intended goal, it seems natural that language teachers should foster strategic competence among their students and provide learning opportunities to develop communication strategies.

Reacting to the issue whether learning strategy instruction be explicit or integrated as part of the regular language class, Chamot (2005, p. 123) is of the view that explicit instruction is far more effective. She defines explicit language-learning strategy instruction as follows: "Explicit instruction includes the development of students' awareness of their strategies, teacher modelling of strategic thinking, identifying the strategies by name, providing opportunities for practise and self-evaluation (Chamot, 2005, p. 123)". Chamot (2005, p. 123) lists about ten researchers who favour explicit strategy instruction. They include O'Malley and Chamot (1990), Cohen (1998, 2003), Chamot and El-Dianary (1999), and Shen (2003). Chamot (2005) is optimistic that the study of language-learner strategies will continue to develop so long as second-language acquisition researchers seek to understand different learner characteristics and so long as language educators and methodologists continue their quest for more effective instructional approaches. She is confident that strategy instruction can contribute to development of learner mastery and autonomy and increased teacher expertise, and recommends that additional research in specific language learning contexts is essential to realising its potential to enhance second language acquisition and instruction. The current author was inspired by this recommendation to conduct this study in Ghana and to find out if strategy instruction in Ghanaian schools will really lead to improved student performance.

In his submission of the importance of strategy instruction to learners, Luke (2006) traces its roots, presents outcomes of studies on it, and predicts its promise as a powerful research-based practice that results in improved student performance. He observes that strategy instruction emerged as a result of investigating and exploring the approaches used by "good learners". He cites Rubin (1975), Pressley, Heisel, McCormick, and Nakamura (1982), Pressley (1989), and Logan, Olson, and Lindsey (1993) among others, as studies conducted on what good learners do. Luke (2006, p. 2) explains that the underlying premise of these investigations and explorations was that if researchers discovered what good learners did and do when they read, write, listen, etc., teachers and parents could teach poor or struggling learners to do what good learners do and thereby improve their performance (Luke, 2006, p. 2). These early studies cited above reveal that good learners take very specific and systematic actions that less effective learners typically do not. They also reveal that students can be taught to use strategies that they have not developed themselves. Luke $(2006$, p. 1) observes that strategy instruction supplies students with the same tools and techniques that effective learners use in their attempt to understand and learn new material. The current researcher shares the view that, indeed, strategy approaches to learning new concepts and skills are often what separate good learners from poor ones.

Rajamoney (2008) investigates the use of language-learning strategies after strategy training in an ESL classroom in Malaysia. Her study involved 42 Form Four students from different races in an urban government secondary school. The ESL students were of intermediate level of proficiency. The primary objective of the study was to identify the types of language-learning strategies that the students would employ after undergoing strategy training. The study also aimed at analysing the students' own perceptions about the use of language-learner strategies in the second-language learning process. It came to light that, after the strategy instruction, the students employed various metacognitive, cognitive, affective, social, and compensatory strategies; before the training session, the students did not know about language-learner strategies and did not also know about the benefits of using these strategies in learning English. The findings also reveal that there is a need for encouraging strategy training. This, Rajamoney (2008) asserts, will enhance second language learning among students.

Oxford (1990, p. 17) had earlier suggested that teachers should not only teach learner-strategies directly to their students but should also provide training on how to transfer such strategies to other learning situations, and Ellis 
(1994, p. 558) says "The study of learning strategies holds considerable promise, both for language pedagogy and for explaining individual differences in L2 learning". Other researchers who have demonstrated that instruction in language-learner strategies actually helps students achieve success in language learning include Carrell, Pharis, and Liberto (1989), Cohen (1999), Mendelsohn (1994), Nunan (1995), and Simmons (1996). The current researcher drew inspiration from these studies.

\section{Method}

\subsection{Participants and Setting}

115 students of a public junior high school (JHS) at Madina, a suburb of Accra, Ghana were involved in a one-year longitudinal study. Fifty-seven of this number constituted an experimental class and 58 comprised the control group. The reason for adopting these two groups is given in the following sub-section. The JHS level in Ghana forms the final component of the K-9 basic education system and students receive instruction through the medium of English. The basic school consists of two years of kindergarten education, six years of primary education, and three years of junior high education. Junior high schools, therefore, admit primary school graduates and, manifestly, prepare them to gain admission into senior high schools and other second cycle institutions. The JHS level is a terminal point and products that pass the BECE are awarded certificates by the WAEC. The certificate indicates the various subjects studied by the candidate and the grades obtained in each subject. About $50 \%$ of basic school leavers are offered admission into senior high, technical, and other trade schools. JHS leavers are neither employed into the formal sector of the economy nor recruited for professional training because they do not possess the minimum requirements set for entry into the formal sector.

There are two main categories of basic schools in Ghana, private and public. Private basic schools in Ghana are established and owned by individuals. They charge comparatively high fees and, usually, only the wealthy educate their wards there. In Ghana, political appointees, directors of department, key business men and women mostly educate their wards in private basic schools. Private basic schools in Ghana are known as international schools. Ghanaians who cannot afford to pay fees charged by the international schools send their wards to public basic schools. Pupils in public basic schools in Ghana do not pay fees. Each pupil is supplied furniture, textbooks, and exercise books. Some public basic schools benefit from the government school-feeding program where pupils are fed in school once a day. It is generally agreed in Ghana that private basic school pupils outperform their public basic school counterparts. This junior high school was chosen for this study because of its proximity to the University of Ghana, the station of the current researcher.

\subsection{Negotiation of Objectives and Procedures}

This researcher introduced himself to the headmistress of the junior high school and discussed his intention for collaboration to conduct a study in her school. Apparently, the head was herself a teacher of English and showed much interest in the project. She held the B. Ed. (English) degree and had taught English as a curriculum subject at the high school level in Ghana for about 20 years. Another efficient language teacher was invited and the three constituted the action research committee. This language teacher had taught English at the basic school level for over 10 years and had also taught at the teacher-training college level for 3 years. She held the B. Ed. (Ghanaian Language) and the MA (TESL) degrees. Since the study was to take the form of action research, to investigate a real practical problem confronting the public school system in the country, meetings were convened and the nature, the objectives, and the benefits both parties would derive from the project were discussed. The part each party would play in the collaboration was also clearly negotiated: this author was to play the role of researcher; the language teacher was to play the role of teacher; and the headmistress was to play the role of administrator, primarily to ensure that the students were available and ready for studies.

The ultimate data that the pedagogical intervention sought to influence was the 2009 BECE results of the experimental class, and the procedure followed to access these data was made clear from the outset of the project. Firstly, the pedagogical intervention would begin in September 2008 and end in April 2009. Secondly, at the beginning of the 2008/09 academic year, students in the three final-year classes would be reshuffled so that each class would have equal number of fast, average, and slow learners. Finally, each class would be registered for the BECE as a school and the results of the two participating cohorts would be contrasted to determine the effect of the intervention.

At the commencement of the seven-month pedagogical intervention, it was found unnecessary to reshuffle the three final-year classes because it was observed through their form two end-of-year examinations results that the students were evenly distributed in the various classes. As agreed upon, the English lessons were taught by the language teacher; she taught both the experimental and the control classes. The headmistress ensured that the students were ready for class. She also ensured that teacher-student contact hours were not interrupted 
unnecessarily. The current researcher observed class proceedings and put down notes during the lessons. He also answered questions posed to him by the other two members of the action research committee and offered suggestions to the language teacher before and after each lesson.

\subsection{Pre-Intervention Task}

Participants in both groups were assigned a specific writing task to execute in their two separate classrooms. This was meant to determine their repertoire of language-learner strategies and also to find out whether the two groups used similar or different strategies. The task assigned them was: Your school wants to excel in all areas of school life. Tell us two things that should be done so that your school will excel. In both groups the students appointed a chair to direct the discussion and a secretary to write down the proceedings. Only points agreed upon by the class were to be written down by the secretary. Many students spoke, all listened, the secretaries wrote the proceeding, and four of them read portions of what was written. The proceedings were video-taped and analysed. The task executed by the children predisposed them to deploy certain language-learner strategies in the classroom. It was later observed that the same strategies, language switch, decoding, regression, and conferencing, were exhibited by the two groups.

\subsection{Pedagogical Intervention}

The pedagogical facility (independent variable) that was infused into the teaching process in the experimental class was explicit instruction of language-learner strategies. The headmistress told the experimental class that one reason why some students easily score Grade "A" in English is that they use specific strategies that enable them to listen better, speak better, read better, and write better and that the current researcher and the teacher wanted to help to equip them with these strategies. The students became enthused and comported themselves throughout the intervention period. The teacher helped the students to recognise and then to identify by name the strategies they already used for different tasks. She modelled strategies that were new to the class and created opportunities for them to practise to use them. The strategies are listed below. (Also refer to Tables 1-4). Additionally, there was usually an open discussion of reasons why students used the strategies they identified.

By the middle of the first term, the experimental group was shown video clips in which various listening, speaking, reading, and writing strategies were deployed. Occasionally, the class was shown video clips in which young language learners were performing a learning task and the class was asked to pinpoint instances of strategy use. These are examples of exclusive strategy-instruction procedures administered in class. By the end of the first term, students in the experimental group could tell the specific strategy deployed by a colleague and how that strategy helped to achieve the desired result. The students could also distinguish productive strategies from less productive ones. By the beginning of the second term, the experimental group had realised the benefits of using productive language-learner strategies and had started applying these to situations relating to the learning of the other nine curriculum subjects.

By the end of the intervention, 4 listening strategies had been learnt: guessing intelligently, clarification seeking, paraphrasing, and confirmation. The class had also learnt 5 speaking strategies: direct appeal, avoidance, fillers, monitoring audience's comprehension, and paraphrasing. That is not all: the students had also learnt 2 reading strategies: monitoring and deriving meaning from context. Additionally, the class was taught 6 writing strategies: conferencing, grouping, explaining, summarising, peer review, and editing. The specific listening, speaking, reading, and writing strategies learnt, their working definitions, and excerpts have been included as Appendices "A", "B", "C", and "D" respectively.

\subsection{Post-Intervention Task}

Toward the end of the second term, the same writing task that the experimental and the control groups executed during the pre-intervention stage was assign the two groups to see if they would do something differently this time. As before, each class nominated a chair to direct the discussion and a secretary to write down the proceedings. They brainstormed for ideas and eventually settled on a number of issues. The control group exhibited 7 strategies: the 4 used during the pre-intervention exercise and 3 others; they remained at conference till the end of the two hours allotted them. Their class proceedings were video-taped and analysed. But members of the experimental group did many things differently. They spent 40 minutes at their opening conference where they brainstormed as a way of generating ideas and when they had settled on issues to write on, they drafted the first paragraph together and then broke up into six groups. Each group developed one issue in a paragraph. After reading and peer-revising their drafts, the six groups edited their paragraphs and converged at conference once more to write the conclusion. The group sessions and the final conference also lasted 40 minutes each. The proceedings were video-taped and analysed. 


\section{Results and Discussion}

This section is in two parts. The first part focuses on the strategies exhibited by members of the two groups during the post-intervention exercise and their implications to language teaching. The second section focuses on the effect of the strategy training in relation to the BECE English results of the experimental and the control groups as published by the WAEC.

\subsection{Learner Strategies Deployed During Posttest}

In all, the experimental class was taught 17 specific language-learner strategies. These have been categorized into the broad functional headings of listening, speaking, reading, and writing strategies and each has been assigned a working definition. It is important to indicate from the outset that this categorization is not neat. For example, the deployment of a particular learner strategy may facilitate the completion of a speaking task and at the same time facilitate the comprehension of a listening task. In a situation like this, the strategy may be described in terms of speaking or listening depending on whether the strategy is being functionally related to the speaker or to the listener respectively. Therefore, this functional categorization of the strategies was adopted for the sake of convenience.

\subsubsection{Listening Strategies}

Listening strategies are procedures that language learners deploy to enable them to understand clearer what is being said. The listening strategies exhibited by the experimental and the control groups during the post-intervention exercises have been summarised in Table 1. As shown in Table 1, we observe that the control group exhibited only one listening strategy, guessing, and this was used by two participants, Students D and E. The first guess turned out to be wrong because it was not informed by the context of speech (refer to Appendix "E"). We argue that the second guess made by Student $\mathbf{E}$ happened to be right, not necessarily because he made an intelligent guess but more probably, because there was no other option. The speaker pointed to the cane on the table; there were only two objects involved.

However, the students in the experimental class used four different listening strategies, guessing, clarification seeking, paraphrasing, and confirmation. In terms of quality, we observe that the four strategies exhibited by the experimental class are of higher quality than the two guesses made by the control class. For example, the interruption made by Student 8, "some money for petrol" (refer to Appendix "A") is an intelligent guess because that was exactly what Student 7 wanted to say. We suggest that the difference in both the quantity and the quality of strategies used by the two groups is the result of the effect of the strategy training the experimental class received.

Table 1. Listening strategies deployed by the participants

\begin{tabular}{|c|c|c|c|c|c|}
\hline \multirow{2}{*}{\multicolumn{2}{|c|}{$\begin{array}{l}\text { Specific Strategy } \\
\text { Deployed }\end{array}$}} & \multicolumn{2}{|c|}{ Group } & \multirow{2}{*}{ Brief Strategy Description } & \multirow{2}{*}{$\begin{array}{l}\text { Example of Strategy Use } \\
\text { (Transcribed Verbatim) }\end{array}$} \\
\hline & & Control & Experimental & & \\
\hline 1 & Guessing & Exhibited & Exhibited & $\begin{array}{l}\text { The learner anticipates } \\
\text { what the speaker intends to } \\
\text { say and interrupts. }\end{array}$ & $\begin{array}{l}\text { 1. That's the teacher's } \\
\text { table. } 2 \text {. Lashing } 3 \text {. Some } \\
\text { money... }\end{array}$ \\
\hline 2 & $\begin{array}{l}\text { Seeking } \\
\text { clarification }\end{array}$ & $\begin{array}{l}\text { Not } \\
\text { Exhibited }\end{array}$ & Exhibited & $\begin{array}{l}\text { The learner asks that what } \\
\text { has been said be explained. }\end{array}$ & $\begin{array}{l}\text { Please what disease is } \\
\text { called "ill-health"? }\end{array}$ \\
\hline 3 & Paraphrasing & $\begin{array}{l}\text { Not } \\
\text { Exhibited }\end{array}$ & Exhibited & $\begin{array}{l}\text { The learner restates what } \\
\text { the speaker has already } \\
\text { said using other words. }\end{array}$ & $\begin{array}{l}\text { Really! The school band } \\
\text { will make our school } \\
\text { popular. }\end{array}$ \\
\hline 4 & Confirmation & $\begin{array}{l}\text { Not } \\
\text { Exhibited }\end{array}$ & Exhibited & $\begin{array}{l}\text { The learner is not sure of } \\
\text { what he hears. He repeats } \\
\text { what he hears, what he had } \\
\text { expected to hear, or both. }\end{array}$ & $\begin{array}{l}\text { Did I hear distinct or } \\
\text { distant? }\end{array}$ \\
\hline
\end{tabular}




\subsubsection{Speaking Strategies}

These are a category of techniques that learners use in order that they will better convey their message. The speaking strategies used by the participants have been summarised in Table 2. We observe that the control group deployed three speaking strategies, direct appeal, avoidance, and language switch, in the course of performing the post-intervention task. But the experimental group displayed five strategies including fillers, monitoring audience comprehension, and paraphrasing. Does this mean that when a learner undergoes strategy training, she is more capable of using a variety of strategies than if she has not?

In terms of quality, the strategies used by the two groups are incongruent. For example, both Students $\mathbf{C}$ and $\mathbf{2}$ made a direct appeal (refer to Appendices "E" and "B" respectively) but whereas Student C paused, pointed to the cane on the table before making the appeal, Student 2 did not pause; she deployed the filler "erhm"and managed to complete her sentence by using another strategy, avoidance before eventually directly appealing to her teacher "please, what do you call it?". She avoided the term "lesson notes" and used the words "what they look on to teach us". Another important point of contrast has to do with unnecessary non-fluency characterised by the speech of members of the control group. We observe that in the control group, speakers paused considerably before deploying a strategy thereby betraying themselves. But in the experimental group, speakers rather used fillers when they were not sure of what to say next and, in so doing, they did not create unnecessary suspicion. So strategy training equips the speaker with a repertoire of strategies from which the speaker spontaneously deploys appropriate strategies whenever performing a speaking task.

Table 2. Speaking strategies deployed by the participants

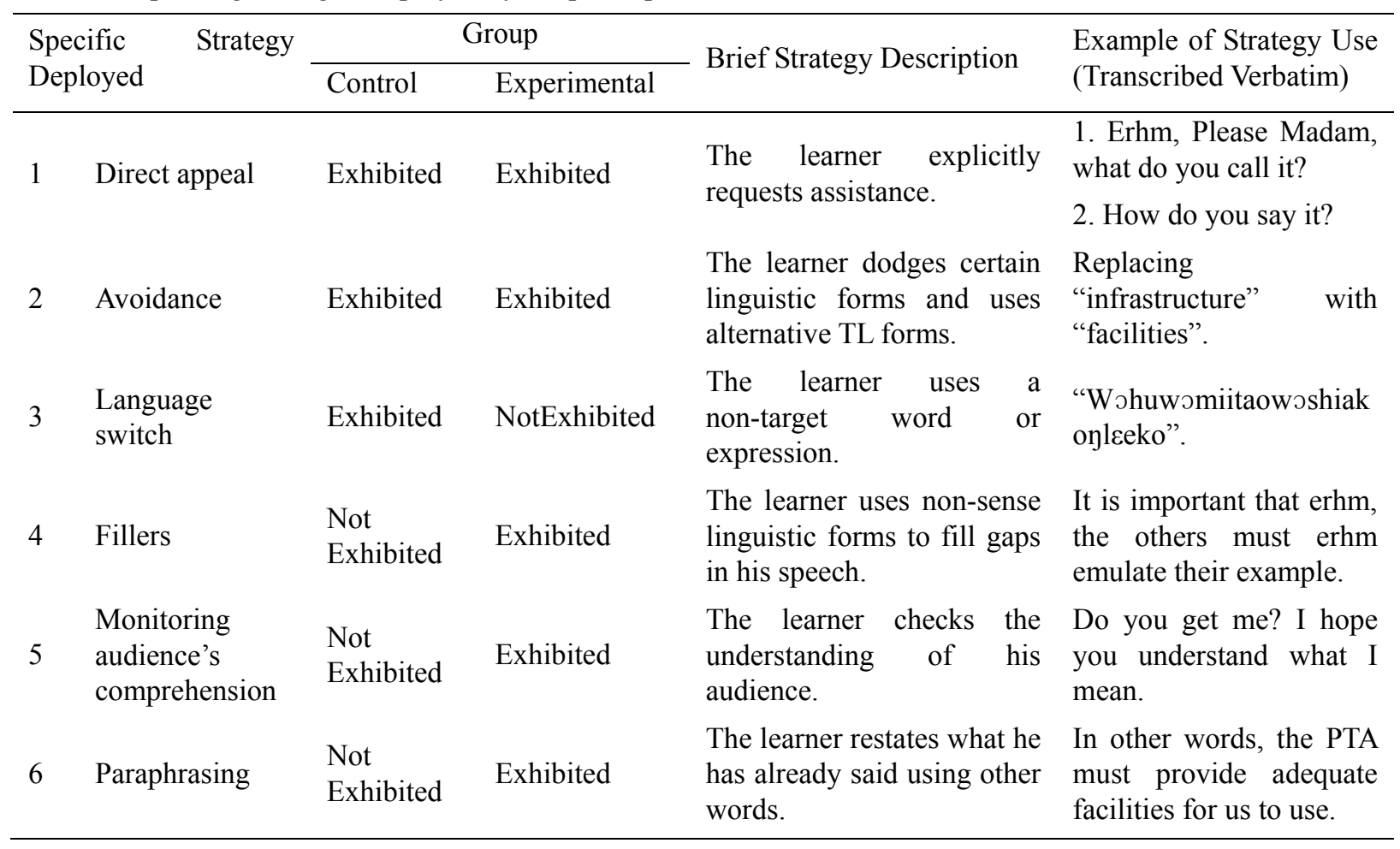

\subsubsection{Reading Strategies}

Reading strategies are procedures that learners follow to enable them to complete or, at least, to attempt a reading task. Some reading strategies have been observed to be more effective than others. Less effective strategies are exhibited in the process of merely running the eyes across and down the page. But more effective strategies enable the language learner to search for the thought that was in the mind of the author and which now lies in the meaning of the words which are before the learner. Reading strategies deployed by the participants included decoding, regression, monitoring, and deriving meaning from context. Table 3 summarizes the reading strategies adopted by the participants. 
The control and the experimental groups displayed two different reading strategies each. But close observation reveals that the strategies deployed by the control group are usually associated with beginner readers while those deployed by the experimental group are linked with effective readers. For example, Student 16 monitors what he reads and derives meaning from the text. As a result, he determines that "expanse" and "infracture" are miswritten and are likely to be "expand" and "infrastructure" respectively. Notice that to be able to do this, he uses another strategy, the filler "erh", to get enough time to derive the most appropriate forms.

Also worthy of note is that the way the control group used the reading strategies they deployed is different from the way the products of the intervention claimed would have used same strategies. For example, Student $\mathbf{F}$ decoded the word "assured" as /a+ssu+red/ and this led to mispronunciation. But the beneficiaries of the strategy training who were questioned on how they would decode "assured" said they would decode it as /as + sure $+\mathrm{d} /$ and this leads to a better pronunciation. So, strategy instruction programmes enable beneficiaries to use strategies intelligently. The actual proceedings of participant interaction in which these reading strategies were used have been transcribed verbatim and included in this paper as Appendix " $\mathrm{C}$ ".

Table 3. Reading strategies deployed by the participants

\begin{tabular}{|c|c|c|c|c|c|}
\hline \multirow{2}{*}{\multicolumn{2}{|c|}{$\begin{array}{l}\text { Specific Strategy } \\
\text { Deployed }\end{array}$}} & \multicolumn{2}{|c|}{ Group } & \multirow{2}{*}{ Brief Strategy Description } & \multirow{2}{*}{$\begin{array}{l}\text { Example of Strategy Use } \\
\text { (Transcribed Verbatim) }\end{array}$} \\
\hline & & Control & Experimental & & \\
\hline 1 & Decoding & Exhibited & Not Exhibited & $\begin{array}{l}\text { The learner uses letter-sound } \\
\text { knowledge to read a word. }\end{array}$ & $\begin{array}{l}\text { Pronouncing assured as } \\
\text { 1. } / \mathrm{a}+\mathrm{ssu}+\mathrm{red} /\end{array}$ \\
\hline 2 & Regression & Exhibited & Not Exhibited & $\begin{array}{l}\text { The learner reads what he } \\
\text { has already read. }\end{array}$ & $\begin{array}{l}\text { If the head, if the } \\
\text { headmistress does... }\end{array}$ \\
\hline 3 & Monitoring & $\begin{array}{l}\text { Not } \\
\text { Exhibited }\end{array}$ & Exhibited & $\begin{array}{l}\text { The learner is able to detect } \\
\text { errors contained in the text } \\
\text { and corrects them as he } \\
\text { reads. }\end{array}$ & $\begin{array}{l}\text { The PTA must erh expand } \\
\text { our school infrastructure. }\end{array}$ \\
\hline 4 & $\begin{array}{l}\text { Deriving } \\
\text { meaning from } \\
\text { context }\end{array}$ & $\begin{array}{l}\text { Not } \\
\text { Exhibited }\end{array}$ & Exhibited & $\begin{array}{l}\text { The learner derives meaning } \\
\text { of unfamiliar words from } \\
\text { context. }\end{array}$ & $\begin{array}{l}\text { The PTA must erh } \\
\text { expanse our school } \\
\text { infracture. }\end{array}$ \\
\hline
\end{tabular}

\subsubsection{Writing Strategies}

These refer to procedures that learners adopt to enable them to successfully complete a writing task. Writing strategies include conferencing, grouping, explaining, summarising, peer review and editing. The writing strategies demonstrated by the participants have been summarised in Table 4 . We observe that only one writing strategy, conferencing, was used by the control group. This lack confirms Chamot's (2005, p. 121) observation that "writing in a second language is arguably the most difficult of the modalities in which to achieve communicative competence". We concede that conferencing is an effective way of generation ideas for an essay; it enables all the participants to come together to find appropriate topics and to gather information on them. So, it may occur before the actual writing begins and may also be adopted during and after the actual writing stage. However, it is not productive to adopt conferencing alone as a writing strategy. As was done by the experimental class after the intervention, conferencing was alternated with grouping. Additionally, other writing strategies like explaining, summarising, peer review, and editing were used both at conference and during the group work sessions.

Grouping, as a writing strategy, refers to the procedure where participants of a writing session are split into cells and are assigned specific tasks to accomplish within a specific time frame. During the group work, issues raised were explained, decisions arrived at were summarised, paragraphs written were revised, and sections rewritten were edited. So, in consonant with Chamot $(2005$, p. 121) the present study recognises that instruction in writing strategies can be beneficial for second language learners. The actual proceedings of participant interaction in which these writing strategies were used have been transcribed verbatim and included in this paper as Appendix "D". 
Table 4. Writing strategies deployed by the participants

\begin{tabular}{|c|c|c|c|c|c|}
\hline \multirow{2}{*}{\multicolumn{2}{|c|}{$\begin{array}{l}\text { Specific Strategy } \\
\text { Deployed }\end{array}$}} & \multicolumn{2}{|c|}{ Group } & \multirow{3}{*}{$\begin{array}{l}\text { Brief Strategy Description } \\
\text { Learners come together to } \\
\text { brainstorm. }\end{array}$} & \multirow{3}{*}{$\begin{array}{l}\begin{array}{l}\text { Example of Strategy Use } \\
\text { (Transcribed Verbatim) }\end{array} \\
\ldots \text { We want to share } \\
\text { ideas. ... Let's start with } \\
\text { you. What do you think? }\end{array}$} \\
\hline & & Control & Experimental & & \\
\hline 1 & Conferencing & Exhibited & Exhibited & & \\
\hline 2 & Grouping & $\begin{array}{l}\text { Not } \\
\text { Exhibited }\end{array}$ & Exhibited & $\begin{array}{l}\text { Learners are put into teams } \\
\text { to work together to } \\
\text { complete a learning task. }\end{array}$ & $\begin{array}{l}\text { We will number } 1,2 \text {, up to } \\
6 \text {. Those who will number } \\
1 \text { will form Group } 1 \text { and so } \\
\text { on. }\end{array}$ \\
\hline 3 & Explaining & Exhibited & Exhibited & $\begin{array}{l}\text { The learner ensures that } \\
\text { what he writes is clearly } \\
\text { explained. }\end{array}$ & $\begin{array}{l}\text { We'll use that time to learn } \\
\text { more things and will excel. }\end{array}$ \\
\hline 4 & Summarizing & $\begin{array}{l}\text { Not } \\
\text { Exhibited }\end{array}$ & Exhibited & $\begin{array}{l}\text { The learner restates his } \\
\text { ideas in a concise manner. }\end{array}$ & $\begin{array}{l}\text { So, when we work hard, } \\
\text { we'll excel. }\end{array}$ \\
\hline 5 & Peer Review & $\begin{array}{l}\text { Not } \\
\text { Exhibited }\end{array}$ & Exhibited & $\begin{array}{l}\text { Learners exchange their } \\
\text { write ups and revise the } \\
\text { contents. }\end{array}$ & $\begin{array}{l}\text { Here we will revise what } \\
\text { others have composed. }\end{array}$ \\
\hline 6 & Editing & $\begin{array}{l}\text { Not } \\
\text { Exhibited }\end{array}$ & Exhibited & $\begin{array}{l}\text { The learner ensures that } \\
\text { discrete language errors in } \\
\text { grammar, vocabulary, } \\
\text { spelling, are corrected. }\end{array}$ & $\begin{array}{l}\text { It's time for us to do what's } \\
\text { called editing. ... }\end{array}$ \\
\hline
\end{tabular}

\subsection{BECE English Results}

This subsection briefly discusses the BECE English results of the control and the experimental classes and finds out if there is any possible relationship between the strategy training programme given to the experimental class and their brilliant performance in English as published by the WAEC. In April 2009, the BECE was written and in August the same year, the results were released by the West African Examinations Council. An application seeking hard copies of the results of the two groups was granted by the examinations council. The results received were analysed and included in this paper as Appendices " $F$ " and " $G$ ". A summary of the analysis is shown in Table 5. The table shows the number of candidates that obtained Grade 1, Grade 2, Grade 3, etc. by both the experimental and the control groups.

Table 5. Analysis of 2009 BECE English language results

\begin{tabular}{lllll}
\hline \multirow{2}{*}{$\begin{array}{l}\text { Grade Obtained in } \\
\text { English Language }\end{array}$} & \multicolumn{2}{l}{ Control Group } & \multicolumn{2}{l}{ Experimental Group } \\
\cline { 2 - 5 } & $\begin{array}{l}\text { Number of } \\
\text { Candidates }\end{array}$ & \% of Candidates & $\begin{array}{l}\text { Number of } \\
\text { Candidates }\end{array}$ & \% of Candidates \\
\hline One & 14 & 24.13 & 55 & 96.49 \\
Two & 29 & 50.0 & 2 & 3.51 \\
Three & 13 & 22.41 & 0 & 0.0 \\
Four & 2 & 3.45 & 0 & 0.0 \\
Total & 58 & 100 & 57 & 100 \\
\hline
\end{tabular}

All the members in the experimental group obtained Grade One in English, except two candidates who got Grade Two. According to the headmistress of the school, this performance is the best BECE results the school has attained since its establishment in 1993. Out of the 58 candidates in the control group, 14 had Grade One, 29 obtained Grade Two, 13 had Grade Three, and 2 obtained Grade Four. We suggest that the pedagogical facility supplied the experimental group created a favourable environment for the effective language learners to add to their strategies and to share these with the average ones. The average students also made the best use of the 
opportunity and together their hard work paid off. The control group, unfortunately, did not get this platform.

\section{Conclusion and Recommendations}

The hypothesis tested in this study is confirmed; if all other variables remain constant, basic school students who have received instruction in language-learner strategies will perform better in English than those who have not been exposed to language-learner strategies. This conclusion is consonant with findings from recent studies on strategy instruction (including Macaro, 2001; Carrier, 2003; Vandergrift, 2003; Wong \& Nunan, 2011; Sadeghi \& Khonbi, 2013; Schwartz, Mendoza, \& Meyer, 2013). By extension, therefore, if learners in primary and junior high schools in Ghana are given training in strategy use, the required outcomes in English would be attained. Indeed, this is an important implication for teaching English as a second language in Ghanaian schools. Another implication of this finding relates to English remediation programmes ran in the tertiary institutions in Ghana. Thus, with the exposure, skills, and experience they would have acquired, products of strategy training programmes from the basic school level would be able to maintain appropriate proficiency levels as they climb the academic ladder, through high school, to the tertiary level. In this way, the universities would not have to contend with mounting English language enhancement programmes for their students.

Additionally, the findings of this study lead to the conclusion that one of the key ingredients that separate successful language learners from less successful ones has to do with learner's repertoire of strategies. It therefore becomes vital that second language learners are equipped with productive strategies through strategy training. In this fashion, they will build an adequate stock of strategies from which to draw when engaged in a language task. This will enable them to eventually become autonomous language learners. Certainly, the learner mastery and autonomy that Chamot (2005, p. 123) talks about is sufficiently demonstrated by the performance of the experimental cohort presented in this study. It is fathomable that Ellis $(1994$, p. 558) anticipates that the study of learner strategies has considerable promise, not only for language teaching but also for explaining individual differences in second-language learning.

The study provides evidence of the positive effect of language-learner strategy instruction at the basic school level in Ghana and suggests that one powerful way by which students at that level can step up performance in English is to teach them to use productive learner strategies. We recommend that, at the primary school level, learners be coached in learner strategies to become autonomous language learners; at the high school level, ample opportunities be created for students to further develop the skills they have already acquired; at the college level, teacher trainees be exposed to a variety of ways to equip their prospective clients with knowledge, skills, and attitudes that will make them independent language learners.

\section{References}

Burns, A. (2010). Doing Action Research in English Language Teaching. New York: Routledge.

Carrell, P. L., Pharis, B. G., \& Liberto, J. C. (1989). Metacognitive strategy training for ESL reading. TESOL Quarterly, 23(4), 647-673.

Carrier, K. A. (2003). Improving high school English language learners' second language listening through strategy instruction. Bilingual Research Journal, 27, 383-408.

Chamot, A. D. (2005). Language learning strategy instruction: Current issues and research. Annual Review of Applied Linguistics, 25, 112-130.

Chamot, A. U., \& El-Dianary, P. (1999). Children's learning strategies in language immersion classrooms. Modern Language Journal, 83(3), 319-338.

Choudhary, Z. J., Al-thubaiti, T. S., \& Uthman, A. (2013). "Effects of English Language Proficiency on the Choice of Language Learning Strategies by Saudi English-major Undergraduates". English Language Teaching, 6(1), 35-47.

Coghlan, D., \& Brannick, T. (2009). Doing Action Research in your own Organization (3rd ed.). London: Sage.

Cohen, A. D. (1998). Strategies in Learning and Using a Second Language. London: Longman.

Cohen, A. D. (1999). Language learning strategy instruction and research. In S. Cotterall, \& D. Crabbe (Eds.), Learner Autonomy in Language Learning: Defining the Field and Effecting Change (pp. 61-68).

Cohen, A. D. (2003). The learner's side of foreign language learning: Where do style, strategies, and task meet? International Review of Applied Linguistics, 41(4), 279-291.

Dakubu, M. E. K. (1988). The Languages of Ghana. London: Kegan and Paul.

Ellis, R. (1994). The Study of Second Language Acquisition. Oxford: Oxford University Press. 
Faucette, P. (2001). A pedagogical perspective on communication strategies: Benefits of training and an analysis of English language teaching materials. Second Language Studies, 19(2), 1-40.

Gillette, B. (1994). The role of learner gaols in L2 success. In J. P. Lantolf, \& G. Appel (Eds.), Vygotskian approaches to second language research (pp. 195-213). Oxford: Oxford University.

Griffiths, C. (2003). Language Learner Strategy Use and Proficiency (Ph.D. thesis, University of Auckland, New Zealand).

Kellerman, E. (1991). Compensatory strategies in second language research: A critique, a revision and some (non-) implications for the classroom. In R. Phillipson, E. Kellerman, L. Selinker, M. Sharwood-Smith, \& M. Swain (Eds.), Foreign and Second Language Pedagogy Research (pp. 142-162). Clevedon, UK: Multilingual Matters.

Logan, J. W., Olson, M. W., \& Lindsey, T. P. (1993). Lessons from champion spellers. Journal for the Education of the Gifted, 13(1), 89-96.

Luke, D. S. (2006). The power of strategy instruction. Evidence for Education, 1(1), 1-12.

Macaro, E. (2001). Learning Strategies in Foreign and second Language Classrooms. London: Continuum.

Mendelsohn, D. J. (1994). Learning to listen. San Diego: Dominie Press.

Mills, E. G. (2011). Action Research: A Guide to the Teacher Researcher. Boston: Pearson Education Inc.

Nunan, D. (1992). Research Methods in Language Learning. Cambridge: Cambridge University Press.

Nunan, D. (1995). Closing the gap between learning and instruction. TESOL Quarterly, 29(1), 133-158.

O’Malley, L. M., \& Chamot, A. U. (1990). Learning Strategies in Second Language Acquisition. Cambridge: Cambridge University Press.

Oxford, R. L., \& Nyikos, M. (1989). Variables affecting choice of language learning strategies by university students. Modern Language Journal, 73, 291-300.

Oxford, R. L. (1990). Language Learning Strategies: What Every Teacher Should Know. Rowley, Mass.: Newbury House.

Oxford, R. L. (1993). Instructional implications of gender differences in language learning styles and strategies. Applied Language Learning, 4(1-2), 65-94.

Pressley, M. (1989). Strategies that improve children's memory and comprehension of text. Elementary School Journal, 90(1), 3-32.

Pressley, M., Heisel, B. E., McCormick, C. G., \& Nakamura, G. V. (1982). Memory strategy instruction with children. In Brainerd, C. J., \& Pressley, M. (Eds.), Progress in Cognitive: Vol. 2. Verbal Processes in Children (pp. 125-159). New York: Springer-Verlag.

Rajamoney, S. S. (2008). A Study of the use of Language Learning Strategies after Strategy Training among Form Four ESL Students (Unpublished M.A. thesis, Universiti Sains Malaysia).

Rees-Miller, J. (1993). A critical appraisal of learner training: Theoretical bases and teaching implications. TESOL Quarterly, 27, 679-689.

Rubin, J. (1975). What the "good language learner" can teach us. TESOL Quarterly, 9(1), 41-45.

Sadeghi, K., \& Khonbi, Z. A. (2013). Learners' Starting Age of Learning EFL and Use of Language Learning Strategies. English Language Teaching, 6(1), 28-34.

Schwartz, A. I., Mendoza, L., \& Meyer, B. (2013). The impact of text structure reading strategy instruction in a second language: Benefits across languages. The Language Learning Journal. http://dx.doi.org/10.1080/09571736.2013.837092

Shen, W. W. (2003). Current trends of vocabulary teaching and learning strategies for ESL settings. Fen Chia Journal of Humanities and Social Science, 7, 187-224.

Simmons. (1996). A study of strategy use in independent learners. In R. Pemberton, E. S. L. Li, W. W. F. Or, \& H. D. Pierson (Eds.), Taking Control: Autonomy in Language Learning. Hong Kong: Hong Kong University Press.

Vandergrift, L. (2003). From prediction to reflection: Guiding students through the process of L2 listening. Canadian Modern Language Review, 59, 425-440. 
Wong, L. L., \& Nunan, D. (2011). The learning styles and strategies of effective language learners. System, 39, 144-163.

World Bank Population Data. (2012). Retrieved November 23, 2013, from http://data.worldbank.org/country/ghana

Appendices

Appendix A

Listening Strategies Deployed by the Experimental Group and Excerpts

1. Guessing

This strategy is said to have been used when a listener anticipates what the speaker intends to say. Student 7 delays in saying some money for petrol, filling the gap with the filler "erhm". In the process, Student 8 predicts what Student 7 intends to say and interrupts her.

Student 7: I have heard that teachers in Ghana are not paid well. So, every month, the PTA should erhm give themerhm [She pauses briefly]

Student 8: some money for petrol.

Student 7: Exactly, some money for petrol so that they will be happy.

2. Seeking clarification

When the learner does not understand what has been said and consequently asks that what has been said be explained, we say that the listener is seeking clarification. In the following exchange, Student 10 deploys this strategy when she wanted to understand the meaning of ill-health.

Student 9: I also support the view that the PTA should build a decent canteen for us. In this way, every student would like to eat there and we will not suffer ill-health.

Student 10: Please, what disease is called ill-health?

Student 9: Oh, ill-health? Ill-health just means "sickness".

3. Paraphrasing

In relation to listening, this strategy is said to have been used when a listener restates what the speaker has already said using other words. Usually, the listener paraphrases because he wants to verify his own understanding of what he has heard. Sometimes, the listener paraphrases when he wants to suggest a better way of expressing what he has heard. In the extract below, Student 12 suggests a better way of expressing what he heard Student 11 say.

Student 11: The other day, somebody spoke that the school should form a school band. Yes, the band can play during the independence anniversary celebration and this will make many people know our school.

Student 12: Really! The school band will make our school popular.

Student 13: This's a good idea.

\section{Confirmation}

This strategy is said to have been used when the listener is not sure about what he has heard and verifies by repeating what he heard, or what it ought to be, or both. Confirmation may take the form, "Did you say ...?" "Is it ...?" "Did I hear ...?" When this strategy is adopted, the listener expects the speaker to repeat that part he is not sure about.

Student 14: Many, I mean a huge number of student come to school every day from "distint" places and traffic can sometimes be extremely heavy. So, the point about corporal punishment must be emphasised.

Student 15: Did I hear distinct or distant?

Student 14: I mean distant. Thank you for the correction.

Appendix B

Speaking Strategies Deployed by the Experimental Group and Excerpts

1. Direct appeal

This strategy refers to the situation where the language learner is not sure of a technical word or expression and resolves the problem by appealing directly to the appropriate authority available to supply the appropriate term. 
In the excerpt below, Student 2 is not sure of the term "lesson notes" and appeals directly to the teacher to supply that term.

Student 2: I hear some of the teachers would not do erhm what they look on to teach us; erhm please, what do you call it?

Teacher: Lesson notes?

Student 3: Yes. They have to prepare their lesson notes so that they can teach better.

\section{Avoidance}

When a speaker does not say what he wants to say because he fears that he will make an error and so he resolves the problem by using an alternative word or expression, we say that the speaker has deployed avoidance strategy. In the scene below, Student 3 uses the avoidance strategy beautifully without creating much suspicion.

Student 3: I am talking about the need to expand the schoolin [He pauses briefly], I mean the school facilities such as classrooms, the library, and the ICT room.

\section{Fillers}

Fillers are linguistic forms that speakers use to fill gaps in their speech. They may result from tiredness, nervousness, anger, emotional stress, memory lapses, anxiety, or preoccupation with something else. Fillers may be used, particularly, when a speaker gets stuck and is thinking about what to say next. Below is an instance where Student 4 uses the filler "erh" to enable him to think about what to say next.

Student 4: Some of the teachers are extremely hard working. It is important that [He pause briefly] erh the others erh emulate their example.

4. Monitoring audience comprehension:

Monitoring refers to the process of checking, verifying, or correcting comprehension in the course of speaking. In a speaking task, the language learner may verify his audience's understanding of what he has been saying. Student 5 uses this strategy when she says "Do you get me? I hope you understand what I mean" in the scene captured below.

Student 5: The place where we buy food during break is not nice. The place is not cemented and there are no tables there. The school needs a proper canteen where we can eat. Do you get me? I hope you understand what I mean. When it rains, for example, ...

\section{Paraphrasing}

In relation to speaking, this strategy is said to have been used when a speaker restates what he has already said using other words. Usually, paraphrasing is deployed when the speaker suspects that what has just been said has not been understood clearly. In trying to make his audience understand better what he has said, Student 6 paraphrases.

Student 6: I agree with her. What she said is very true. The school's infrastructure must be expanded. In other words, our Parent and Teacher Association must provide adequate facilities for us to use.

Appendix C

Reading Strategies Deployed by the Experimental Group and Excerpts

\section{Monitoring}

In relation to reading, monitoring refers to the process of reading a text in such a way that the reader is able to detect mistakes and errors contained in the text as he reads it. This results in non-fluency. Student $\mathbf{1 6}$ deploys this strategy when he reads:

Student 16: The PTA must "erh" expand ["Expand" was written as "expans"] our school infrastructure ["Infrastructure" was written as "infrasture"] so that ...

When a highly-proficient L2 learner monitors her reading, she may end up reconstructing some of the sentences she considers structurally or grammatically inappropriate.

\section{Deriving Meaning from Context}

When a reader comes across an unfamiliar word or expression but is able to get the meaning because of the other words used in the text or because of the situation created and described in the text, we say the reader derives meaning from context. Student 16 uses this strategy in the extract below: 
Student 16: The PTA must "erh" expand ["Expand" was written as "expanse"] our school infrastructure ["Infrastructure" was written as "infracture"] so that ...

So, when a reader monitors her reading she naturally derives meaning of unfamiliar words from the context.

Appendix D

Writing Strategies Deployed by the Experimental Group and Excerpts

\section{Conferencing}

This strategy refers to the situation where all the participants come together to find appropriate topics and to gather information on them. This occurs before the actual writing begins. Conferencing may also be adopted during and after the actual writing stage. The excerpt that follows shows the planning process of the participants in the experimental group.

Student 1 (The Class Captain): Thank you Madam. Ok, let's start. We want to share ideas. Everyone is to say one thing that the school should do to excel in all areas of school life. So, you can say what you think the headmistress should do, or what our teachers should do, or what our parents should do. You can even say what the Parent Teacher Association (PTA) and others should do. Let's start with you [pointing to Student 21]. What do you think?

\section{Grouping}

This strategy refers to the situation where learners are put into groups so that they will generate ideas on one issue and write their ideas down.

Student 1: Now listen! Now, we've finished writing our introduction and we know we have three issues to write on. Let's form groups so that each group will develop one issue into a paragraph. No, we are 57 and so I think we need 6 groups. Two groups will write on one issue and we'll adopt the better one. We will number 1, 2, 3, up to 6. Those who will number 1 will form Group 1; those who will number 2 will form Group 2 and so on.

Many Students: [React spontaneously.] Alright!

\section{Explanation}

This strategy is said to have been used when learners ensure that issues they raise in their writing are clearly explained. In the extract that follows, Student 18 explains further the issue raised by Student 17.

Student 17: The PTA should employ more cleaners so that we'll get more time to study.

Student 18: That's true! Part of the PTA levy we pay every term will be used to pay the additional cleaners. Then we will not have to clean the compound and the classrooms every morning. We'll use that time to learn more things and will excel.

\section{Summarizing}

Summarizing refers to the process where ideas are written in a concise manner. In summarizing, ideas expressed in long sentences are restated in shorter sentences. In the scene below, Student $\mathbf{2 0}$ adopts the summary strategy by restating the idea expressed by Student 19.

Student 19: If we want the school to excel, then we the students must wake up early every morning to come to school early every day. Also, when we come to school, we must study hard and do all our exercises. When we go home too, we must do all our homework before we go to bed.

Student 20: So, when we work, hard we'll excel.

Student 19: Yes.

\section{Peer review}

This strategy refers to the procedure where groups or individuals exchange their write ups and revise the contents. The peer review strategy allows sentences or phrases to be deleted or added. This strategy also allows ideas to be moved around, expanded upon, and made clearer. In the excerpt that follows, Student 1 initiates the strategy of peer review.

Student 1: We are now coming to peer review. Here, we'll revise what others have composed. So, now [pauses] so now let's begin.

\section{Editing}

The editing strategy refers to the procedure where learners ensure that discrete language mistakes are corrected. 
These include mistakes in grammar, vocabulary, sentence structure, and spelling. The use of this strategy ensures that learners' writings are made presentable before they are submitted. In the excerpt that follows, Student 1 initiates the editing strategy.

Student 1: May I have your attention please. It's time for us to do what's called editing. Here, each group will give the work back to the owners and they'll correct the mistakes themselves. So, let's give them back to them?

Appendix E

Strategies Deployed by the Control Group and Excerpts

1. Language switch (Speaking strategy)

This strategy relates to the act of using two languages in a sentence or a discourse. Student A realises that her initial statement is not clear so she switches to Ga, her mother tongue.

Student A: We want the Music Master to make a school band [She pauses and switches to Ga] "Wo hu womiitao wəshi akoy $1 \varepsilon$ eko". [Translation from Ga meaning "we would like to shake our bodies (by marching) too"].

2. Avoidance (Speaking strategy)

When a speaker does not say what he wants to say because he fears that he will make an error and so he resolves the problem by using an alternative word or expression, we say that the speaker has deployed avoidance strategy. In the scene below, the student avoids the word admit and rather uses bring.

Student B: I want to talk about admission of students. The headmistress should not [He pauses and restarts the sentence.]. The headmistress should not bring too many people into one classroom.

\section{Direct appeal (Speaking strategy)}

This strategy refers to the situation where the language learner gets stuck and resolves the problem by asking a speaker available to tell him the appropriate word or expression. In the excerpt below, Student $\mathbf{C}$ gets stuck and appeals to her classmates to supply the word lashing.

Student C: I want the teachers to stop [She pauses and points to a cane on the teacher's table.] how do you say it?

Student D: That is the teacher's table.

Student C: No

Student E: Do you mean lashing?

Student C: Yes, they should stop lashing us when we come to school late.

4. Guessing (Listening strategy)

This strategy is said to have been used when a listener anticipates what the speaker intends to say. The guess supplied may be right or wrong. Student $\mathbf{C}$ gets stuck and wants her classmates to supply the word lashing but Student $\mathbf{D}$ wrongly supplied the phrase the teacher's table. Realising that the guess made by Student $\mathbf{D}$ was wrong, Student E quickly supply the word lashing.

Student C: I want the teachers to stop [She pauses and points to a cane on the teacher's table.] how do you say it?

Student D: That is the teacher's table.

Student C: No

Student E: Do you mean lashing?

Student C: Yes, they should stop lashing us when we come to school late.

5. Decoding (Reading strategy)

This is a bottom-up strategy and relates to the use of letter-sound knowledge to read a word and possibly to connect to its meaning. In using this, the reader builds meaning by first focusing on the smallest unit of language, letters and sounds, and then moving to larger units of language (syllables, words, phrases, clauses, sentences, paragraphs, and whole text). In the excerpt below, Student $\mathbf{F}$ uses the decoding strategy to read the word assured pronouncing it as /a-su-red/.

Student F: If the head [He pauses and resumes.] if the headmistress does this, we will be assured [He pronounces 'assured'as /a+su+red/] of aca [He pauses and resumes.] academic excellence. 


\section{Regression (Reading strategy)}

Regression has to do with repeating what has already been read. This usually occurs when the reader has difficulty reading the subsequent word. Student $\mathbf{F}$ adopts the regression strategy (also called rereading) in the scene below.

Student F: If the head [He pauses and resumes.] if the headmistress does this, ...

\section{Conferencing}

This strategy refers to the situation where all the participants come together to find appropriate topics and to gather information on them. This occurs before the actual writing begins. Conferencing may also be adopted during and after the actual writing stage. The excerpt that follows shows the planning process of the participants in the experimental group.

Student G (Control group class captain): Thank you. Alright! We want to start. Everybody will say one thing that he or she wants somebody to do so that the school will excel in all areas of school life. What do you want the headmistress to do, or what do you want the teachers or the PTA to do? Or what for you think we students can do? Who wants to start? Tell us something.

Appendix F

Analysis of English Results of Experimental Class

Published by the West African Examinations Council

Basic Education Certificate Examinations (Ghana-2009)

Results List by Participating Schools (Pages 5314-8) School No. 106032

\begin{tabular}{llll}
\hline Candidate's & $\begin{array}{l}\text { Grade Obtained } \\
\text { in English }\end{array}$ & $\begin{array}{l}\text { Candidates } \\
\text { Index No. }\end{array}$ & $\begin{array}{l}\text { Grade Obtained } \\
\text { in English }\end{array}$ \\
\hline XXXXXX001 & 1 & XXXXXX030 & 1 \\
XXXXXX002 & 1 & XXXXXX031 & 2 \\
XXXXXX003 & Transferred & XXXXXX032 & 1 \\
XXXXXX004 & 1 & XXXXXX033 & 1 \\
XXXXXX005 & 1 & XXXXXX034 & 1 \\
XXXXXX006 & 1 & XXXXXX035 & 1 \\
XXXXXX007 & 1 & XXXXXX036 & 1 \\
XXXXXX008 & 1 & XXXXXX037 & 1 \\
XXXXXX009 & 1 & XXXXXX038 & 1 \\
XXXXXX010 & 1 & XXXXXX039 & 1 \\
XXXXXX011 & 1 & XXXXXX040 & 1 \\
XXXXXX012 & 1 & XXXXXX041 & 1 \\
XXXXXX013 & 1 & XXXXXX042 & 1 \\
XXXXXX014 & 1 & XXXXXX043 & 1 \\
XXXXXX015 & 1 & XXXXXX044 & 1 \\
XXXXXX016 & 1 & XXXXXX045 & 1 \\
XXXXXX017 & 1 & XXXXXX046 & 1 \\
XXXXXX018 & 1 & XXXXXX047 & 1 \\
XXXXXX019 & 1 & XXXXXX048 & 1 \\
XXXXXX020 & 1 & XXXXXX049 & 1 \\
XXXXXX021 & 1 & XXXXXX050 & 1 \\
XXXXXX022 & 1 & XXXXXX051 & 1 \\
XXXXXX023 & 1 & XXXXXX052 & 1 \\
XXXXXX024 & 1 & XXXXXX053 & 1 \\
XXXXXX025 & 2 & XXXXXX054 & 1 \\
XXXXXX026 & 1 & XXXXX055 & 1 \\
XXXXXX027 & 1 & XXXXXX057 & 1 \\
XXXXXX028 & 1 & & 1 \\
XXXXXX029 & 1 & & \\
\hline & & & \\
& & &
\end{tabular}


Appendix G

Analysis of English Results of Control Class

Published by the West African Examinations Council

Basic Education Certificate Examinations (Ghana-2009)

Results List by Participating Schools (Pages 5319-5323) School No. 106069

\begin{tabular}{|c|c|c|c|}
\hline $\begin{array}{l}\text { Candidate's } \\
\text { Index No. }\end{array}$ & $\begin{array}{l}\text { Grade Obtained in } \\
\text { English }\end{array}$ & $\begin{array}{l}\text { Candidate's } \\
\text { Index No. }\end{array}$ & $\begin{array}{l}\text { Grade Obtained in } \\
\text { English }\end{array}$ \\
\hline$\overline{X X X X X X 001}$ & 3 & XXXXXX030 & 3 \\
\hline XXXXXX002 & 2 & XXXXXX031 & 3 \\
\hline XXXXXX003 & 2 & XXXXXX032 & 2 \\
\hline XXXXXX004 & 1 & XXXXXX033 & 2 \\
\hline XXXXXX005 & 2 & XXXXXX034 & 2 \\
\hline XXXXXX006 & 1 & XXXXXX035 & 1 \\
\hline XXXXXX007 & 2 & XXXXXX036 & 3 \\
\hline XXXXXX008 & 3 & XXXXXX037 & 3 \\
\hline XXXXXX009 & 2 & XXXXXX038 & 2 \\
\hline XXXXXX010 & 3 & XXXXXX039 & 2 \\
\hline XXXXXX011 & 2 & XXXXXX040 & 4 \\
\hline XXXXXX012 & 1 & XXXXXX041 & 1 \\
\hline XXXXXX013 & 1 & XXXXXX042 & 1 \\
\hline XXXXXX014 & 1 & XXXXXX043 & 3 \\
\hline XXXXXX015 & 3 & XXXXXX044 & 2 \\
\hline XXXXXX016 & 1 & XXXXXX045 & 1 \\
\hline XXXXXX017 & 1 & XXXXXX046 & 2 \\
\hline XXXXXX018 & 2 & XXXXXX047 & 2 \\
\hline XXXXXX019 & 2 & XXXXXX048 & 1 \\
\hline XXXXXX020 & 1 & XXXXXX049 & 2 \\
\hline XXXXXX021 & 2 & XXXXXX050 & 3 \\
\hline XXXXXX022 & 1 & XXXXXX051 & 2 \\
\hline XXXXXX023 & 2 & XXXXXX052 & 2 \\
\hline XXXXXX024 & 3 & XXXXXX053 & 1 \\
\hline XXXXXX025 & 2 & XXXXXX054 & 2 \\
\hline XXXXXX026 & 2 & XXXXXX055 & 3 \\
\hline XXXXXX027 & 3 & XXXXXX056 & 2 \\
\hline XXXXXX028 & 2 & XXXXXX057 & 2 \\
\hline XXXXXX029 & 3 & XXXXXX058 & 2 \\
\hline
\end{tabular}

\section{Copyrights}

Copyright for this article is retained by the author(s), with first publication rights granted to the journal.

This is an open-access article distributed under the terms and conditions of the Creative Commons Attribution license (http://creativecommons.org/licenses/by/3.0/). 